\title{
Skala zewnętrznych ograniczeń w kredytowaniu agrobiznesu (na przykładzie województwa mazowieckiego)
}

\section{Wstęp}

Działalność kredytowa stanowi podstawową formę zarobkowania banku i ma decydujący wpływ na jego wynik finansowy oraz kondycję ekonomiczna [4]. Działania banku powinny zatem zmierzać nie w kierunku ograniczania kredytowania, lecz w kierunku minimalizacji ryzyka kredytowego [11]. Owe ryzyko jest szczególnie wysokie w przypadku kredytowania działalności rolniczej. Charakterystyczne dla rolnictwa sezonowość produkcji oraz długie jej cykle prowadzą do sezonowego zróżnicowania przychodów i dużej ich rozbieżności w czasie z koniecznymi do poniesienia wydatkami [2]. Konsekwencją tego jest niewydolność dochodowa, która wynika również z ograniczonego dopływu do gospodarstw środków finansowych ze źródeł kredytowych [5]. Analogiczne kłopoty z pozyskaniem kapitału obcego ma zdecydowana większość podmiotów gospodarczych stanowiących klasyczną niejako sferę agrobiznesu. Jak dotychczas dominują tu przede wszystkim przedsiębiorstwa małe i średnie, $z$ reguły też słabe kapitałowo [1].

Przytoczone cechy podmiotów działających w agrobiznesie przemawiaja za kredytowaniem ich na zasadach preferencyjnych. Preferencje polegają na stosowaniu obniżonej stopy procentowej w rezultacie dotacji z budżetu, w którego imieniu działa Agencja Restrukturyzacji i Modernizacji Rolnictwa [7]. Tani kredyt zwiększa zainteresowanie tą formą finansowania. $Z$ drugiej strony należy podkreślić, że polityka taniego kredytu deformuje rachunek ekonomiczny i nie stwarza zabezpieczenia przed nieefektywnym wykorzystaniem środków, które są za kredyt nabywane [3].

W związku z powyższym banki mają prawo odroczyć, a nawet odmówić udzielenia kredytu lub żądać dostatecznie atrakcyjnego zabezpieczenia jego spłaty, a w przypadku pozytywnej decyzji kredytowej - zaproponować inną kwotę kredytu od wartości wynikającej z wniosku. Fakt nieuzyskania przez 
rolnika albo innego mieszkańca wsi kredytu we wnioskowanej wysokości lub też całkowite odmówienie im kredytu przez instytucję finansową określa się w literaturze jako wystapienie zjawiska zewnętrznego ograniczenia kredytowego [6].

\section{Materiał i metodyka}

Celem artykułu była próba określenia skali zewnętrznych ograniczeń kredytowych w agrobiznesie. Określenie skali omawianego zjawiska przeprowadzono na podstawie linii kredytowych cieszących się największym zainteresowaniem ze strony potencjalnych kredytobiorców, czyli kredytów: inwestycyjnych podstawowych (IP), na zakup gruntów rolnych (KZ), dla młodych rolników (MR) oraz branżowych (BR).

Do realizacji celu posłużyły dane zawarte w sprawozdaniach z działalności Agencji Restrukturyzacji i Modernizacji Rolnictwa (ARiMR) oraz sprawozdaniach Wojewódzkiego Ośrodka Doradztwa Rolniczego w Warszawie (WODR) z lat 2000-2002. Dane dotyczą województwa mazowieckiego, ponieważ udział tego województwa zarówno w strukturze liczbowej, jak i kwotowej udzielonych kredytów jest najwyższy w kraju.

W opracowaniu wykorzystano metody porównania oraz analizy danych wynikających z wyżej wymienionych sprawozdań. Rozważania nie będą obejmowały ograniczeń kredytowych typu wewnętrznego oraz takich, których źródłem jest interwencja władz publicznych w rolnicze i wiejskie rynki kredytowe. $\mathrm{Z}$ tego względu grono zainteresowanych preferencyjnymi kredytami inwestycyjnymi zostanie na potrzeby artykułu zawężone tylko do rolników oraz przedsiębiorców, którzy uzyskali pozytywną opinię Wojewódzkiego Ośrodka Doradztwa Rolniczego w Warszawie.

\section{Charakterystyka wybranych linii kredytowych}

Preferencyjne kredyty inwestycyjne przyznane na terenie województwa mazowieckiego stanowią 16-19\% ich ogólnej liczby i około $15 \%$ wartości. W strukturze kredytów zaciąniętych przez mazowieckie podmioty agrobiznesu dominują kredyty z linii MR, których udział w ostatnich latach przekraczał $50 \%$. Tak duża popularność kredytów dla młodych rolników wynika z najniższej stopy procentowej, okresu spłaty do 15 lat oraz możliwości zastosowania 
karencji w spłacie kapitału trwającej 2 lata. Ponadto, kredyty MR mogą być kierowane do rencistów posiadających orzeczenie o stanie zdrowia niezawierające przeciwwskazań do samodzielnego prowadzenia gospodarstwa rolnego, co stanowi wyjątek w kredytowaniu inwestycji na zasadach preferencyjnych. Nieuzasadnione jest ograniczenie wieku kredytobiorcy do 40 lat [8].

Podobnymi warunkami spłaty, ale węższym zakresem przedmiotowym charakteryzują się kredyty na.zakup ziemi. Średnio co czwarty kredyt udzielony w województwie mazowieckim jest przeznaczany na zakup gruntów w celu utworzenia nowego lub powiększenia istniejącego gospodarstwa rolniczego. W strukturze kwotowej udział kredytów KZ kształtuje się na poziomie $6 \%$.

W przypadku kredytów inwestycyjnych podstawowych i branżowych maksymalny okres spłaty wynosi 8 lat. Kredyty z linii IP mają możliwość 2-letniej, natomiast kredyty udzielane w ramach programów branżowych - 3-letniej karencji w spłacie kapitału. Zainteresowanie tymi kredytami jest niższe od cechującego kredyty dla młodych rolników oraz na zakup gruntów rolnych, przy czym ich wartość w przeliczeniu na każde przedsięwzięcie jest wyższa.

Łączny udział wszystkich omawianych linii kredytowych zarówno w strukturze liczbowej, jak i kwotowej kredytów inwestycyjnych objętych dopłatami ARiMR na Mazowszu przekracza 98\%.

\section{Zewnętrzne ograniczenia kredytowe w agrobiznesie}

\section{Zewnętrzne ograniczenia w kredytowaniu gospodarstw prowadzonych przez młodych rolników}

$\mathrm{Z}$ danych warszawskiego WODR wynika ogólna tendencja, polegająca na zwiększeniu zainteresowania kredytami dla młodych rolników. W 2001 r. liczba pozytywnie rozpatrzonych wniosków była o ponad $20 \%$ większa od wielkości z 2000 r., a w 2002 r. - o kolejne $35 \%$. Zmiany o podobnym charakterze wystąpiły również w przypadku łącznej kwoty wnioskowanych kredytów, przy czym tempo przyrostu w 2002 r. było 5 razy niższe od tempa z 2001 r. Podobne trendy w liczbie oraz wartości udzielonych kredytów MR na terenie województwa mazowieckiego ukazują dane Agencji Restrukturyzacji i Modernizacji Rolnictwa $z$ lat 2000-2002. Zestawienie danych pochodzących ze wspomnianych źródeł odnośnie do kredytów dla młodych rolników zawiera tabela 1. 


\section{Tabela 1}

Skala zewnętrznych ograniczeń $w$ kredytowaniu gospodarstw prowadzonych przez młodych rolników na terenie województwa mazowieckiego w latach 2000-2002

\begin{tabular}{|c|c|c|c|c|c|c|c|c|}
\hline \multirow[b]{2}{*}{ Rok } & \multicolumn{3}{|c|}{ Udzielone kredyty } & \multicolumn{3}{|c|}{$\begin{array}{c}\text { Wnioski pozytywnie } \\
\text { rozpatrzone przez } \\
\text { Wojewódzki Ośrodek } \\
\text { Doradztwa Rolniczego }\end{array}$} & \multirow{2}{*}{ 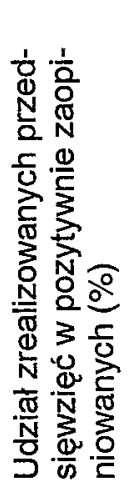 } & \multirow{2}{*}{ 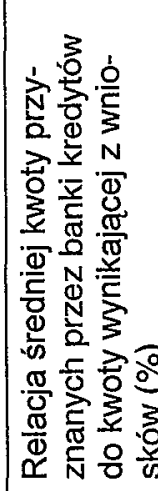 } \\
\hline & $\begin{array}{l}\stackrel{\pi}{N} \\
\stackrel{N}{=}\end{array}$ & 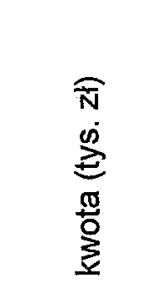 & 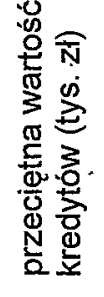 & $\begin{array}{l}\stackrel{0}{N} \\
\stackrel{N}{=}\end{array}$ & 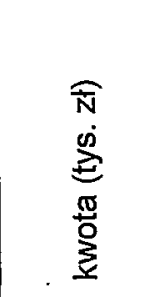 & 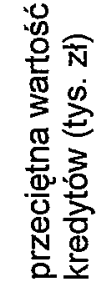 & & \\
\hline 2000 & 1216 & 120496,0 & 99,1 & 1497 & 169155,4 & 113,0 & 81,2 & 87,7 \\
\hline 2001 & 159.1 & 173911,0 & 109,3 & 1816 & 227595,5 & 125,3 & 87,6 & 87,2 \\
\hline 2002 & 2229 & 199205,6 & 89,4 & 2457 & 243347,0 & 99,0 & 90,7 & 90,3 \\
\hline
\end{tabular}

Źródło: Opracowanie własne na podstawie [9] i [10].

Zaprezentowane dane wskazują na poprawę dostępności do kredytów MR. W analizowanym okresie wystapił wzrost udziału przedsięwzięć przyjętych przez banki do realizacji o prawie $10 \%$. Na podstawie danych tabelarycznych można zaobserwować także zmniejszenie ograniczeń kwotowych przyznawanych kredytów dla młodych rolników. W latach 2000-2001 mazowieccy rolnicy uzyskiwali przeciętnie $87-88 \%$ wartości kredytów wynikających z wniosków, a w 2002 r. relacja ta przekroczyła $90 \%$. Sytuacja taka wynika z rozłożenia przez banki ograniczonych środków pochodzących najczęściej z lokat na sfinansowanie możliwie największej liczby projektów.

\section{Zewnętrzne ograniczenia w kredytowaniu zakupu ziemi}

Kredyty oznaczone symbolem $\mathrm{KZ}$ podobnie jak kredyty MR charakteryzowały się w latach 2000-2002 rosnącym wolumenem. Wyrażone kwotowo zainteresowanie tymi kredytami w 2002 r. zwiększyło się o ponad połowę w porównaniu z $2000 \mathrm{r}$. oraz o $28 \%$ - w porównaniu z $2001 \mathrm{r}$. Podobną tendencją, ale większą dynamiką zmian cechowała się faktycznie udzielona przez banki wartość kredytów na zakup gruntów rolnych. $Z$ kolei liczba przyznanych kredytów była najniższa w 2001 r. i stanowiła około $97 \%$ wielkości z 2000 r. oraz $73 \%$ w porównaniu z 2002 r. (tab. 2). 


\section{Tabela 2}

Skala zewnętrznych ograniczeń $w$ kredytowaniu zakupu gruntów na terenie województwa mazowieckiego w latach 2000-2002

\begin{tabular}{|c|c|c|c|c|c|c|c|c|}
\hline \multirow[b]{2}{*}{ Rok } & \multicolumn{3}{|c|}{ Udzielone kredyty } & \multicolumn{3}{|c|}{$\begin{array}{l}\text { Wnioski pozytywnie } \\
\text { rozpatrzone przez } \\
\text { Wojewódzki Ośrodek } \\
\text { Doradztwa Rolniczego }\end{array}$} & \multirow{2}{*}{ 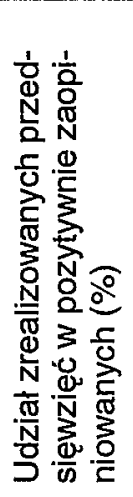 } & \multirow{2}{*}{ 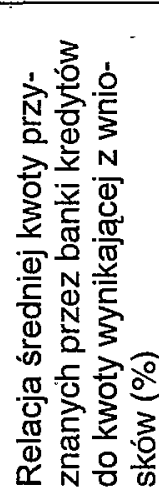 } \\
\hline & $\begin{array}{l}\stackrel{\pi}{N} \\
\stackrel{0}{=}\end{array}$ & 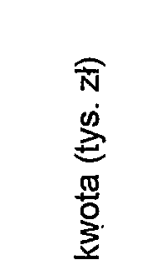 & 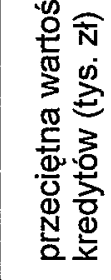 & $\begin{array}{l}\frac{\pi}{N} \\
\stackrel{N}{=}\end{array}$ & 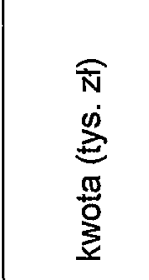 & 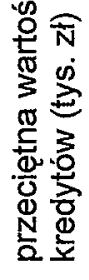 & & \\
\hline 2000 & 779 & 13652,0 & 17,5 & 895 & 15827,6 & 17,7 & 87,0 & 98,9 \\
\hline 2001 & 756 & 15614,0 & 20,7 & 885 & 18907,1 & 21,4 & 85,4 & 96,7 \\
\hline 2002 & 1032 & 22907,2 & 22,2 & 1101 & 24275,5 & 22,0 & 93,7 & 100,9 \\
\hline
\end{tabular}

Źródło: Opracowanie własne na podstawie [9] i [10].

Kierunki zmian w liczbie udzielonych kredytów i pozytywnych opinii są zbieżne $\mathrm{z}$ trendami występującymi we wzajemnej ich relacji. Tendencje te przekładają się także na procentowy stosunek przeciętnej kwoty zaciągniętych kredytów do średniej wartości kredytów wynikającej z pozytywnie zaopiniowanych projektów. Największa dyskryminacja potencjalnych kredytobiorców linii $\mathrm{KZ}$ przez formalne instytucje finansowe miała miejsce w 2001 r., wówczas banki odrzuciły prawie $15 \%$ pozytywnie rozpatrzonych wniosków, a każdy przyznany kredyt stanowił przeciętnie $96,7 \%$ wnioskowanej kwoty. Następny rok charakteryzował się najniższą skalą zjawiska zewnętrznych ograniczeń kredytowych w analizowanym okresie. Spośród pozytywnie zaopiniowanych przedsięwzięć w 2002 r. zostało zrealizowanych 93,7\%, natomiast średnia wartość kredytów na zakup gruntów rolnych była wyższa o około $1 \%$ od wynikającej ze złożonych wniosków. Sytuacja ta stanowi odwrotną do poprzedniej, a wytłumaczeniem jest występowanie w kredytowaniu kosztów transakcyjnych, których poziom oraz udział spada, gdy wzrasta jednostkowa wartość transakcji finansowej i łączny jej wolumen. W przypadku małych (wartościowo) kredytów koszty te mogą stanowić nawet od 15 do $40 \%$ udostępnionych kwot [6]. 


\section{Zewnętrzne ograniczenia w kredytowaniu inwestycji w rolnictwie, przetwórstwie rolno-spożywczym oraz usługach dla rolnictwa}

Zmiany w liczbie i wartości kredytów IP przyjęły podobne kierunki jak te, które miały miejsce $\mathrm{w}$ przypadku kredytów $\mathrm{KZ}$. W podobny sposób kształtowały się w latach 2000-2002 stosunek zrealizowanych przedsięwzięć do pozytywnie zaopiniowanych oraz relacja przeciętnej kwoty zaciagniętych kredytów inwestycyjnych podstawowych do średniej wartości wynikającej z wniosków, która jednak w 2002 r. osiągnęła niższy poziom w porównaniu z $2000 \mathrm{r}$. (tab. 3).

\section{Tabela 3}

Skala zewnętrznych ograniczeń w kredytowaniu inwestycji w rolnictwie, przetwórstwie rolno-spożywczym i usługach dla rolnictwa na terenie województwa mazowieckiego w latach 2000-2002

\begin{tabular}{|c|c|c|c|c|c|c|c|c|}
\hline \multirow[b]{2}{*}{ Rok } & \multicolumn{3}{|c|}{ Udzielone kredyty } & \multicolumn{3}{|c|}{$\begin{array}{l}\text { Wnioski pozytywnie } \\
\text { rozpatrzone przez } \\
\text { Wojewódzki Ośrodek } \\
\text { Doradztwa Rolniczego }\end{array}$} & \multirow{2}{*}{ 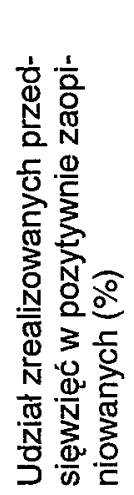 } & \multirow{2}{*}{ 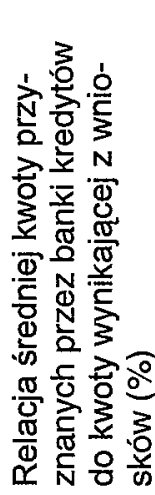 } \\
\hline & $\begin{array}{l}\frac{\mathbb{O}}{N} \\
.0 \\
.0\end{array}$ & 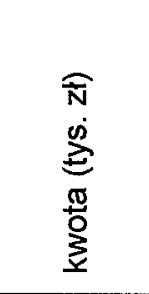 & 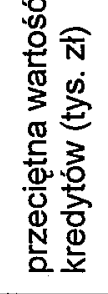 & $\begin{array}{l}\mathbb{N} \\
\stackrel{N}{0}\end{array}$ & 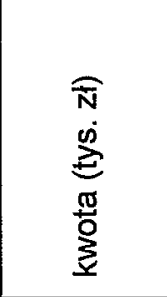 & 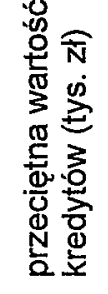 & & \\
\hline 2000 & 458 & 44179,0 & 96,5 & 581 & 81523,9 & 140,3 & 78,8 & 68,8 \\
\hline 2001 & 383 & 48131,0 & 125,7 & 503 & 109543,5 & 217,8 & 76,1 & 57,7 \\
\hline 2002 & 815 & 73685,3 & 90,4 & 948 & 139993,4 & 147,7 & 86,0 & 61,2 \\
\hline
\end{tabular}

Źródło: Opracowanie własne na podstawie [9] i [10].

Dla odmiany 2002 r. charakteryzował się największym odsetkiem zrealizowanych przedsięwzięć inwestycyjnych $\mathrm{w}$ rolnictwie, przetwórstwie rolno-spożywczym i usługach dla rolnictwa. Wówczas stanowiły one $86 \%$ pozytywnie rozpatrzonych planów przez terenowe oddziały Wojewódzkiego Ośrodka Doradztwa Rolniczego w Warszawie. Najwyższa skala zjawiska zewnętrznych ograniczeń kredytowych miała miejsce w 2001 r., kiedy banki odmówiły przyznania kredytu IP niemal co czwartemu wnioskodawcy, natomiast w przypadku decyzji o udzieleniu kredytu godziły się na wypłacenie niespełna $60 \%$ jego kwoty wynikającej z wniosków. 


\section{Zewnętrzne ograniczenia w kredytowaniu inwestycji objętych programami branżowymi}

Ostatnią grupą omawianych kredytów są kredyty branżowe, które cieszyły się największą popularnością w 2000 r., najmniejszą zaś w 2001 r. Liczba przyznanych kredytów BR oraz pozytywnych opinii była w 2000 r. ponaddwukrotnie wyższa od wielkości z 2001 r. Ogólna wartość udzielonych kredytów branżowych i kredytów wynikających z pozytywnie zaopiniowanych projektów przyjęła w analizowanym okresie trend wzrostowy (tab. 4).

\section{Tabela 4}

Skala zewnętrznych ograniczeń w kredytowaniu programów branżowych na terenie województwa mazowieckiego w latach 2000-2002

\begin{tabular}{|c|c|c|c|c|c|c|c|c|}
\hline \multirow[b]{2}{*}{ Rok } & \multicolumn{3}{|c|}{ Udzielone kredyty } & \multicolumn{3}{|c|}{$\begin{array}{l}\text { Wnioski pozytywnie } \\
\text { rozpatrzone przez } \\
\text { Wojewódzki Ośrodek } \\
\text { Doradztwa Rolniczego }\end{array}$} & \multirow{2}{*}{ 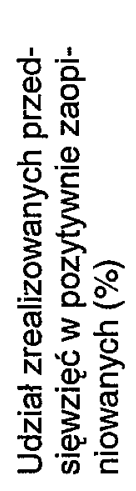 } & \multirow{2}{*}{ 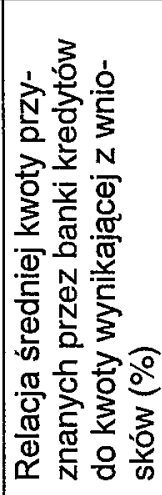 } \\
\hline & $\begin{array}{l}\frac{\pi}{N} \\
\stackrel{0}{=}\end{array}$ & 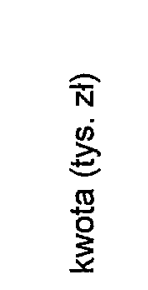 & 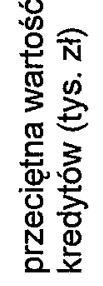 & 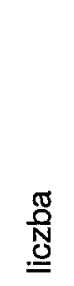 & 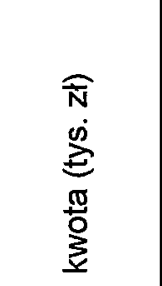 & 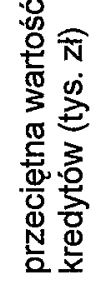 & & \\
\hline 2000 & 420 & 40709,0 & 96,9 & 497 & 50303,3 & 101,2 & 84,5 & 95,8 \\
\hline 2001 & 181 & 48416,0 & 267,5 & 207 & 85152,9 & 411,4 & 87,4 & 65,0 \\
\hline 2002 & 319 & 49514,9 & 155,2 & 363 & 104073,2 & 286,7 & 87,9 & 54,1 \\
\hline
\end{tabular}

Źródło: Opracowanie własne na podstawie [9] i [10].

Tendencję wzrostowa wystapiła także w przypadku udziału zrealizowanych przedsięwzięć $\mathrm{w}$ pozytywnie zaopiniowanych, przy czym drastycznemu zmniejszeniu uległ procentowy stosunek przeciętnej kwoty przyznanych kredytów BR do wnioskowanej ich wartości. W 2000 r. kredytobiorcy uzyskiwali średnio $96 \%$ planowanych kwot, a w 2002 r. już tylko $54 \%$.

\section{Podsumowanie}

Zewnętrzne ograniczenia kredytowe wynikają z wielu czynników, lecz zaprezentowane dane uwydatniają wpływ jedynie kosztów transakcyjnych, których obecność dała się zauważyć w 2002 r. odnośnie do kredytowania zakupu 
ziemi. Wówczas przeciętna wartość udzielonych kredytów była wyższa od wnioskowanej. Sytuację tę można wyjaśnić odrzuceniem przez banki projektów potencjalnie nadających się do kredytowania $z$ racji niskiego zapotrzebowania na kredyt oraz wysokich kosztów transakcyjnych. Z tego względu możliwości obniżania wartości udzielanych kredytów przez formalne instytucje finansowe są również bardzo ograniczone. Przyczyn omawianego zjawiska nie należy jednak zawężać do wysokich kosztów transakcyjnych, ponieważ zewnętrzne ograniczenia kredytowe mogą być spowodowane także innymi, mniej lub bardziej świadomie tworzonymi przez banki finansujące barierami. Przykładem takiej bariery, która ogranicza działalność kredytową instytucji finansowych, a w konsekwencji liczbę i wielkość przyznanych kredytów, jest poziom lokat.

Zaprezentowane dane wskazuja iż banki nakładały najniższe ograniczenia kredytowe na gospodarstwa rolnicze, czyli adresatów linii MR i KZ. Największe trudności sprawiło rolnikom oraz wiejskim przedsiębiorcom otrzymanie kredytu podstawowego inwestycyjnego w $2001 \mathrm{r}$. Z kolei warunki pozyskania kredytów branżowych w latach 2000-2002 należy ocenić jako pogarszające się, gdyż tempo spadku relacji wypłaconych kwot kredytów do wnioskowanych było większe niż tempo wzrostu udziału zrealizowanych przedsięwzięć.

\section{Literatura}

DĘBNIEWSKA M., SOŁOMA A., 2002. Kredytowanie podmiotów w agrobiznesie w rejonie działania Warmińsko-Mazurskiego Banku Regionalnego. Roczniki Naukowe SERiA, tom 4, zeszyt 5, Warszawa-Poznań-Bydgoszcz.

GAJOWIAK D.K., 2003. Wpływ kredytu rolnego na kształtowanie majątku oraz dochodów gospodarstwa specjalizującego się w produkcji mleka. Zeszyty Naukowe Szkoły Głównej Gospodarstwa Wiejskiego w Warszawie, Ekonomika i Organizacja Gospodarki Żywnościowej, nr 51.

GRABOWSKI S., KOWALSKI A., ADAMOWICZ M., 1998. Ekonomika rolnictwa i polityka rolna. Podręcznik dla uczniów średnich szkół rolniczych. FAPA, Warszawa.

KATA R., 2003. Perspektywy kredytowania gospodarstw rolniczych przez banki spółdzielcze w obszarze rolnictwa rozdrobnionego. Acta Scientiarum Polonorum, Oeconomia 2 (1) 2003, Wydaw. SGGW, Warszawa.

KOŻUCH B., KOŻUCH A., 2000. Polityka rolna. Podręcznik dla technikum i szkoły policealnej. WSiP, Warszawa.

KULAWIK J., 2002. Zewnętrzne ograniczenia kredytowe w rolnictwie. Zagadnienia Ekonomiki Rolnej, nr 2-3/2002.

POCZTA W., CZERWIŃSKA-KÁYZER D., 2001. Skłonność do inwestowania w gospodarstwach indywidualnych przy wykorzystaniu kredytów preferencyjnych. Zagadnienia Ekonomiki Rolnej, nr 4-5/2001.

PODSTAWKA M., 2000. Finanse w rolnictwie. Wieś Jutra, Warszawa, s. 84. 
Sprawozdania Wojewódzkiego Ośrodka Doradztwa Rolniczego w Warszawie z lat 2000-2002 .

Sprawozdania z działalności Agencji Restrukturyzacji i Modernizacji Rolnictwa z lat 2000-2002 .

SWACHA C., 1996. Wybrane zagadnienia zarządzania bankiem spółdzielczym. Działalność kredytowa banków oraz warunki uzyskiwania kredytu w rolnictwie. Materiały na seminarium, Katedra Ekonomiki i Organizacji Gospodarstw Rolniczych, Studium Bankowości i Finansów przy Wydziale Ekonomiczno-Rolniczym SGGW, Fundacja „Rozwój SGGW”, Warszawa.

\section{The Scope of External Limitations in Crediting of Agrobusiness (Based on the Masovia Province)}

\section{Abstract}

The study presents external limitations in crediting of agrobusiness in Masovia Province. The scope of them was presented on the example of the most popular four preferential credit lines in the years from 2000 to 2002. In this period the credits for young farmers and for purchases of lands had the lowest scope of external limitations, but the rest of credit lines was characterized by the highest scope of limitations. Main reasons for external limitations of crediting agrobusiness are transaction costs and volume of deposits in banks. External limitations depend on other barriers which are less or more consciously created by formal financial institutions. 